\title{
A New Approach to Weed Management to Mitigate Herbicide Resistance in Argentina
}

\author{
Claudio Rubione and Sarah M. Ward*
}

\begin{abstract}
The evolution of herbicide-resistant weeds is a major concern in the corn- and soybean-producing Pampas region of Argentina, where growers predominantly plant glyphosate-resistant crop varieties and depend heavily on glyphosate for weed control. Currently, 16 weed species in Argentina are resistant to one or more of three different herbicide mechanisms of action, and resistant weed populations continue to increase, posing a serious threat to agricultural production. Implementation of integrated weed management to address herbicide resistance faces significant barriers in Argentina, especially current land ownership and rental patterns in the Pampas. More than $60 \%$ of Pampas cropland is rented to tenants for periods that rarely exceed $1 \mathrm{yr}$, resulting in crop rotation being largely abandoned, and crop export taxes and quotas have further discouraged wheat and corn production in favor of continuous soybean production. In this paper we discuss ways to facilitate new approaches to weed management in Argentina, including legal and economic reforms and the formation of a national committee of stakeholders from public and private agricultural sectors.
\end{abstract}

Nomenclature: corn, Zea mays L., soybean, Glycine max (L.) Merr.

Key words: Argentina, export taxes, herbicide resistance, land tenancy, lease law, Pampas.

\section{Land-Use Changes and the Evolution of Herbicide-Resistant Weeds in Argentina}

The Argentine Pampas, originally a vast flat grassland, covers more than 55 million ha of arable land. The history of land use and patterns of land ownership in this region of Argentina can be broadly divided into three different time periods: (a) the 19th and early 20th centuries when agricultural production was concentrated in large cattle or sheep ranches with some cereal production; (b) the mid-20th century, characterized by land redistribution and the emergence of a rural middle class farming 500 ha or less; and (c) the last decades of the 20th century, in which there was a decline of small and medium farms and an increase of wellcapitalized, large-scale producers farming 2,500 ha or more (Amaral 1998; Barsky et al. 1991; Binimelis et al. 2009; Viglizzo et al. 2011). Changes in land ownership patterns have been accompanied by changes in cropping systems, as production of annual crops in the Pampas steadily increased from 13 million ha in 1988 to 20 million ha just $10 \mathrm{yr}$ later (Sili and Soumoulou 2011). This resulted in a steep decline in forage production for livestock; in a

\footnotetext{
DOI: $10.1614 /$ WS-D-16-00016.1

* First author: Agronomist and Technical Director, Claudio Rubione R\&D, Av. Mitre 1641, 9 De Julio, 6500 Buenos Aires, Argentina; second author: Associate Professor, Department of Soil and Crop Sciences, Colorado State University, Fort Collins, CO 80523. Corresponding author's E-mail: sarah.ward@colostate.edu
}

recent study of the Pergamino district north of Buenos Aires, Cabrini and Calcaterra (2016) reported only $6 \%$ of arable land used for forage production, compared to a Pampas-wide average of $35 \%$ in the late 1980 s (Rótolo et al. 2015). The shift to annual cropping reduced profitability for small farms; an economic modeling study by Bert et al. (2011) showed that farms under 100 ha in the Pampas could not accumulate sufficient capital to survive year-to-year fluctuations in yield and commodity prices. Consequently, many small farmers have opted to rent or sell their land to larger producers farming 500 to over 2,500 ha, who can combine raising crops with cattle production, typically in feedlots (Urcola et al. 2015). Between 1992 and 2002, the number of individual farms in Argentina decreased by $20 \%$, as approximately 60,000 small producers stopped farming (Tomei and Upham 2009; Urcola et al. 2015), and the average farm size increased $25 \%$ over the same period (Choumert and Phelinas 2015). Another recent phenomenon is the emergence over the past 20 yr of "sowing pools" (pooles de siembra) comprised of investors outside the agricultural sector who rent or buy land and contract with third parties for crop management and harvesting, typically large-scale cereal and soy biodiesel production with a focus on short-term returns (Choumert and Phelinas 2015; Urcola et al. 2015). These changes in patterns of ownership resulted in an increase in leased agricultural land in the Pampas from 8 million ha in 1988 to 14.2 
million ha by 2002 (Bert et al. 2011; Sili and Soumoulou 2011); Urcola et al. (2015) reported that in Balcarce district in Buenos Aires province, the percentage of leased farms doubled between 1988 and 2010. By 2013 land leasing had come to predominate as the new agricultural organization model in Argentina, with more than $60 \%$ of land in the main soybean-producing areas farmed under rental agreements, and $90 \%$ of leased agricultural land farmed under fixed-term rental contracts, an increasing proportion of these contracts being for a single growing season (Choumert and Phelinas 2015; Delvenne et al. 2013).

Prior to 1985 , the total area of soybean production in Argentina was approximately 25\% of what it is today (Choumert and Phelinas 2015). A major reason for this change was the introduction of glyphosate-resistant (GR) soybean varieties, which were rapidly adopted by farmers due to easy weed control and lower herbicide costs; within $4 \mathrm{yr}$ of their introduction in 1996, GR varieties comprised over $90 \%$ of soybean grown in Argentina (Penna and Lema 2003). Unlike U.S. farmers, Argentinean farmers who planted GR soybean could legally save their own seed, and an extensive domestic black market for GR soybean seed rapidly reduced planting costs to less than half of those incurred by U.S. growers. Inexpensive imported glyphosate, mainly from China, also made GR soybean an attractive and profitable option for Pampas growers (Leguizamón 2014; Qaim and Traxler 2005). This combination of GR seed and herbicide applied over the top facilitated an increase in Argentine soybean area from approximately 6 million ha prior to 1990 to 21 million ha in 2015 (Compañía Argentina de Tierras 2016). Over the same time period, corn production declined by almost $50 \%$ due to higher production costs and lower profit margins compared to soybeans; approximately 3 million ha was planted to corn in 2015 (Bronstein 2015; Compañia Argentina de Tierras 2016).

In the mid-1980s, weed management practices in Argentina began to change with the introduction of new ALS-inhibiting herbicides (such as imazaquin and chlorimunon) that were much more effective at controlling the weed spectrum in soybeans. A similar phenomenon occurred in the United States, where ALS inhibitors were introduced into the soybean market in the mid-1980s and rapidly became the herbicides of choice, so that by 1995 over $90 \%$ of U.S. soybean acreage was treated with an ALS inhibitor (Shaner 2000). Unfortunately, the continued use of ALS-inhibitors in soybeans, and later in imidazolinone-resistant corn and sunflowers, led to selection for resistant weed populations in both Argentina and the United States. The first case of ALS inhibitor resistance in Argentina was reported in smooth pigweed (Amaranthus hybridus L.) in 1996 (AAPRESID REM 2015; Heap 2016).

A revolution in soybean production in Argentina occurred in the mid-1990s with the introduction of glyphosate-resistant soybean. These new GR varieties appeared to be the answer to herbicide-resistant weeds and-as in the United States-GR technology was rapidly adopted by Argentine farmers (Binimelis et al. 2009); 4 yr following their introduction in 1996, GR varieties comprised over $90 \%$ of soybean production in Argentina (Penna and Lema 2003). Glyphosate, often as multiple applications during the growing season at rates averaging 4,000 $\mathrm{g} \mathrm{ae} \mathrm{ha}^{-1} \mathrm{yr}^{-1}$, became the principal and often the sole herbicide used to control weeds in soybeans, and later in GR corn (Vila-Auib et al. $2008 \mathrm{a}, \mathrm{b})$. This reliance on one mode of action (MOA) inevitably imposed intense selection pressure on weed populations, and the first case of glyphosate resistance in Argentina was reported in 2005 in johnsongrass [Sorghum halepense (L.) Pers.] (Binimelis et al. 2009; Vila-Aiub et al. 2008a). Glyphosate resistance has since been confirmed in nine additional weed species at locations throughout the country (Heap 2016). Glyphosate-resistant weeds are becoming a major problem in Argentine soybean, corn, and sunflower as well as in winter crops such as wheat and barley (AAPRESID REM 2015; Vila-Auib et al. 2008b). Overall, reports of herbicide-resistant weeds have increased rapidly in Argentina since 2008, with cases of resistance currently reported in 16 different species and to three different MOAs nationwide; resistance to multiple MOAs in the same population has been confirmed in three weed species (Heap 2016).

\section{Obstacles to Implementing Herbicide- Resistance Management in Argentina}

As weeds evolve resistance, new strategies will be required for managing herbicide-resistant (HR) weed populations in which one or more previously effective herbicides are now lost, and for maintaining herbicide efficacy as long as possible on weeds that are still susceptible. Effective long-term herbicide-resistance management requires an integrated approach that utilizes diverse methods to reduce selection for weeds that are resistant to 
herbicides or any other control method (Norsworthy et al. 2012). Unfortunately, there are many barriers to implementing integrated weed management (IWM) for effective herbicide-resistance management in Argentina. Among the most serious obstacles are land ownership and renting practices. As already described, patterns of land ownership and tenure in the Pampas, the major agricultural area in Argentina, have changed rapidly in the last few decades. Tenants now crop more than half of all available agricultural land (Bert et al. 2011; Urcola et al. 2015), and much of agricultural production has shifted from family-owned enterprises to land rental and contracted specialized services for planting, harvesting, and marketing (Senesi et al. 2013). This has implications for the management of herbicide-resistant weeds. Surveys conducted in the United States and Europe found that tenant farmers are less likely than owner-operators to adopt best management practices (BMPs) for soil conservation (Sklenicka et al. 2015; Soule et al. 2000) and also are less likely to practice crop rotation (Varble et al. 2016). Similar data are lacking for adoption of herbicide-resistance BMPs among owner vs. tenant farmers. However, studies of BMP adoption for conserving soil and water quality that connect land tenure with grower choices could also apply to herbicide-resistance management. For example, tenants are more focused on short-term income and are less likely to invest in longer-term management strategies than owners (Fraser 2004; Soule et al. 2000). However, evidence that costsharing and other financial incentives can help offset this trend (e.g., Fraser 2004) could usefully inform agricultural policy decisions.

The legal basis for land leases in Argentina is Law No. 13.248 (Arrendamientos Rurales y Aparcerias) passed in 1948 . This law originally stipulated that land rentals should be for a minimum of $3 \mathrm{yr}$, required the tenant to manage the soil and weeds to preserve the agricultural value of the land, and stated that whenever landowners have weed problems, the cost of removing them should be shared with tenants (SAIJ 2016). In practice, these provisions were rarely enforced, due to lack of supervision and resources. In 1980, the law was revised to allow more limited leases for a single crop cycle (typically $1 \mathrm{yr}$ or less). This 1980 revision of Law No. 13.248 provides the current legal framework for agricultural land leases in Argentina, but the law is often circumvented by simply arranging rentals where parties sign a common paper specifying only the area to be leased and the cost of rental; various other informal arrangements have been practiced over the years, such as unregistered oral agreements to lease land, or the landowner providing the field and seed and the tenant providing labor, then dividing the harvest $50: 50$ (Choumert and Phelinas 2015). Since 2007 , requirements that growers register as agricultural producers with the Argentinean Federal Administration of Public Income (AFIP), and declare their cropping plans to qualify for tax reductions, have reduced the number of "unofficial" land leases; potential additional effects of AFIP regulations on farming practices in Argentina are discussed in a later section of this paper. However, the continuing lack of any legal obligation for a landowner to renew a lease means that farmers have no security of tenure or rights to continue farming land they might have cultivated for long periods of time (Choumert and Phelinas 2015).

Since glyphosate-resistant soybeans were introduced in Argentina, the area under no-till has expanded rapidly, improving soil and fallow management but increasing reliance on herbicides for weed control. In 2012, 26 million ha were in no-till; this area continues to increase, and now almost $95 \%$ of soybeans and corn is in no-till production (AAPRESID 2012; Senesi and Ordoñez 2013). Sophisticated planters and huge sprayers are assembled in Argentina, as well as combines and other no-till implements, and satellite monitoring and global positioning system (GPS) mapping have become common in the Argentine Pampas. This trend favors larger well-capitalized producers, whereas landowners unable to work their own farms due to equipment costs and high taxes often rent or sell their land. Choumert and Phelinas (2015) reported in their analysis of factors affecting land rental prices in the Argentine Pampas that almost $75 \%$ of land parcels surveyed were owned by nonproducers, either retired farmers or individuals who had left farming. In many cases, when farmers die, their children choose to study or work elsewhere rather than take over the farm; the land is either rented or sold to new owners, often divided into smaller areas, depending on the number of heirs (Manciana et al. 2009). As land parcels were consequently reduced, the economic minimum area required to support a single family increased to an estimated 300 ha (Fernández 2010). In order to expand production, farmers in the Pampas actively compete for rental land to maintain or increase their cropped area and profit. This has led to a dramatic increase in land rental prices: in 2001, typical rental 
value in U.S. dollars was $\$ 150 \mathrm{ha}^{-1}$, but by 2014 , $\$ 500 \mathrm{ha}^{-1}$ was needed to rent the same piece of land (Compañía Argentina de Tierras 2016). Some of this increase in rental costs reflects improved soybean yields, which are now up to 5 tonnes ha $^{-1}$ compared to the 3 tonnes ha $^{-1}$ that were typical in the 1990s (Compañia Argentina de Tierras 2016). Land rental prices are driven by the attractive profitability of agricultural commodity production in a volatile economy, while high land prices and difficulty of obtaining credit prevent smaller tenant farmers from becoming owners (Choumert and Phelinas 2015).

One of the consequences of this highly competitive marketplace is predominantly short-term leasing of land, with almost all leases for $1 \mathrm{yr}$ or a single cropping season (Binimelis et al. 2009; Choumert and Phelinas 2015). During the1997 to 1998 growing season, 1.8 million ha of soybean were planted in Argentina, $25 \%$ of to GR varieties; by the $2013 / 2014$ season, soybean had expanded to 19.3 million ha, 98\% planted with GR varieties. Over the same period, corn increased from 3.75 to 6 million ha, but wheat and sunflower declined from 5.9 to 3.6 million ha and from 3.1 to 1.3 million ha respectively (Senesi et al. 2016). The current imbalance between soybean hectares and the land planted to other crops indicates that short-term leases are associated with extensive planting of continuous soybean at the expense of longer-term rotations with wheat, corn, and sunflower. In addition, lease contracts generally allow farmers to apply herbicide as many times as needed, with no coordination between successive tenant farmers to manage weeds on the land from one year to another (Manciana et al. 2009). Crop rotation is an essential component of IWM because it facilitates the use of multiple herbicide MOAs and the incorporation of other weed management practices (Norsworthy et al. 2012). However, given current landholding patterns in the Pampas and the widespread focus on short-term profit provided by soybean, there is little incentive for growers to voluntarily implement effective longer-term integrated weed management techniques.

\section{A New Approach to Managing Weeds in Argentina}

A new approach to weed management is needed in Argentina that will diversify management practices and reduce selection for weeds resistant to glyphosate and other herbicides. This will require recognition by landowners, tenant farmers, and government officials that herbicide resistance represents a serious threat to agricultural production in Argentina, and that current agronomic and land leasing practices are driving the rapid increase in herbicide-resistant weeds. The situation in the United States, with 155 unique HR cases (i.e., HR weed species by MOA) reported to date (Heap 2016), could also represent the future for farmers in Argentina if they do not take proactive steps to manage herbicide resistance.

There is an urgent need for implementation of IWM in Argentina. However, this will require monitoring, research, and outreach efforts led by producer organizations and the private sector, and backed by government action to reform the legal framework and tax structure affecting growers. As already described, large areas of arable land in Argentina are now farmed on short term leases, or are owned by outside investors who contract with third parties for crop production and weed management. With long-term land stewardship no longer a priority for producers under these conditions, there is little incentive for voluntary grower-initiated action on managing herbicide resistance. This is especially true where adoption of IWM would raise short-term production costs and reduce immediate profits; growers are unwilling to invest in proactive measures to prevent resistant weeds if their perception is that the immediate costs of such actions outweigh the intangible future benefits of avoiding resistance (Llewellyn and Allen 2006). Where producers making weed management decisions have no long-term vested interest in land that they do not own, effective herbicide-resistance management will require the coordinated effort of stakeholders from both public and private sectors. In the Argentine Pampas, this could be achieved by implementing the following steps.

1. Establish a Database of Affected Fields. Using a standardized protocol to identify, map, and record fields that currently have herbicide-resistant weeds would provide essential information on the current extent of the problem. These data would also provide a baseline for assessing the effectiveness of any future national or regional management initiatives. The private Agriculture No Till Farmers Association (AAPRESID) already maintains some of this information (AAPRESID REM 2015) and could be a major contributor to the establishment of this database. The proposed national committee (see Step 5 below) could maintain records of where herbicide-resistant weeds are present and monitor 
impacts of IWM implementation on the occurrence of herbicide resistance.

2. Record Herbicide Application. Establishing a system for maintaining records of herbicides applied on each field, and requiring this information to be maintained regardless of who farms a field from one year to the next, would be a valuable tool for local implementation of IWM. If landowners were required to keep these records and make them available to tenants, repeated use of the same herbicide MOA by successive growers could be avoided. Keeping these records might also encourage landowners to be more attentive to the risk of herbicide-resistant weeds in their fields, and demonstrate that preventing herbicide resistance provides long-term benefits.

3. Rewrite Leases to Reflect HR Weed Status. IWM adoption by tenant farmers could be further encouraged by modifying leases to identify fields that already have resistant weeds, or that based on past tenancy and management history are at risk of developing herbicide resistance. Such leases could include requirements that the tenant will effectively manage weeds by implementing IWM. Including crop rotation requirements in new leases to break the continuous soybean cycle and allow diversified weed management practices, whether HR weeds are present or not, could also improve IWM adoption on leased land.

4. Revise Current Lease Laws. As already described, the 1980 revision to the 1948 Land Lease Law weakened several key provisions, especially with regard to longer-term leasing that would facilitate crop rotation and implementation of IWM. In 1948, the intent of the law was to encode obligations between farmers and tenants with regard to soil and weed management practices. The original Land Lease Law No. 13.248 states that tenancy should be for periods of 3 or more yr and provides for a new lease and terms to be negotiated after that lease ends. Soil conservation measures are required under the 1948 law, which also states that weed control costs should be shared between contracting parties before a new tenant crops the field (SAIJ 2016). Legal revision that would encourage a return to these principles might help create a more favorable environment for implementing IWM. In particular, if a new legal framework required that leases be extended beyond the current $1 \mathrm{yr}$ or single cropping period, then growers would have greater incentives to adopt multiple-year weed management programs.
Monitoring for compliance could be based on information provided by growers when they selfidentify as agricultural producers at the Federal Administration of Public Income (AFIP) under AFIP Resolution 2300/2007. This resolution requires that producers declare how much land they own or lease, how many hectares they plan to crop, and what crops they plan to sow; registered producers benefit from lower income taxes and reduced value added taxes for grain sold (AFIP 2007). Once growers are registered with AFIP, any change in production options for the year must be declared, including whether they are renting additional land or leasing their land to a tenant; fields are scouted by government agents to ensure compliance. This registration and inspection system could be extended to include details of crop rotation and whether the grower is using recommended weed management practices.

5. Establish a National Herbicide-Resistance Management Committee. A national IWM program could be promoted, monitored, and managed by a committee representing stakeholders from the public and private sectors, and supported by a combination of tax-based funding - possibly similar to crop check-off systems in the United States-and financial contributions from private agricultural companies. Potential committee members include government representatives from the Argentine Agricultural Food and Health Service (SENASA: Servicio Nacional de Sanidad y Calidad Agroalimentaria), INTA (Instituto Nacional de Tecnologia Agropecuaria), and the Argentine Ministry of Agriculture (Ministerio de Agroindustria). However, a committee to promote and monitor IWM might be more effective and have more influence with growers if organized and headed by representatives from the private agricultural sector, including grower associations. Committee members could also include economists, university and private agricultural researchers, crop management consultants, and other expert professionals. The committee would collect and maintain information on the occurrence of herbicide-resistant weeds nationally and the results of management trials, oversee extension educator training, make appropriate IWM recommendations, and certify good field practices. It would also act as a database and communication center for results and information on herbicide resistance from government, university, and private researchers around the country, and would obtain and award funds for research projects addressing herbicide resistance problems. 
6. Modify Export Taxes. Argentina's government has promoted cultivation of soybean as the predominant export crop, generating substantial revenues from a 35\% export tax (Leguizamón 2014). As already described, widespread adoption of GR soybean has led to growers abandoning crop rotations that included wheat and corn. From 2008 onwards, attempts by the Argentinean government to manipulate the domestic wheat market by imposing export quotas and an export tax of $23 \%$ resulted in even more farmers abandoning wheat cultivation; national wheat production fell from 16 million tonnes in 2005 to 8.2 million tonnes in 2013, and was harvested from 3.16 million ha, which was the lowest wheat acreage in Argentina in over $100 \mathrm{yr}$ (Anonymous 2014; SIIA 2016). Argentinean corn growers have also scaled back production in response to price caps and a $20 \%$ export tax, with only 3 million ha harvested in 2014 (Bronstein 2015). Despite high export taxes, growers were attracted by the profit margins, cheapness, and relative ease of GR soybean production, together with the exemption of soybean from the export quotas imposed on wheat and other commodities in an attempt to secure domestic food supplies (Leguizamón 2014). This has resulted in virtual monocropping of GR soybean over large areas; in 2014, 62\% of Argentinean cropland was growing continuous soybean (Bronstein 2015). This lack of diversity in cropping systems, together with heavy reliance on a single-herbicide MOA, rapidly accelerates the evolution of herbicide-resistant weeds.

Eliminating-or at least restructuring-quotas and export taxes might encourage growers to diversify from soybean and adopt more sustainable cropping options. A recent step in this direction was taken with the postelection announcement in November 2015 that export taxes for wheat and corn will be abolished, and export taxes for soybean will be reduced by $5 \%$ year $^{-1}$, starting in 2016 (Mander 2015). Although the immediate intent of these changes is to increase crop exports, making wheat and corn more attractive options for Pampas growers could also encourage a return to crop rotation and provide opportunities for addressing the spread of HR weeds through more widespread IWM implementation.

7. Expand Extension Education and Outreach. A survey published by Binimelis et al. (2009) revealed that many growers in the Argentine Pampas have become what these authors describe as "weed illiterates" who have forgotten-or never knew- integrated weed management practices that predated the widespread adoption of GR crops and consequent glyphosate dependence. Implementation of IWM in Argentina will therefore require extensive educational and outreach programs to communicate effective IWM practices to farmers, with the input of governmental agencies, especially the Argentinean Ministry of Agriculture (Ministerio de Agroindustria de la Nacion Argentina), cooperating with universities and private consultants to develop approved weed management protocolsfrom field management to cleaning of machinery including planters and combines-and communicate them to growers. Studies in the United States have found that appropriately targeted educational outreach raises grower awareness of agricultural and environmental issues, and increases adoption of improved management practices (e.g., Lemke et al. 2010; Propoky et al. 2008; Riar et al. 2013). Continued university-based field research will also be needed to identify the IWM practices that work best for different Argentinean regions and to provide hands-on examples of the effectiveness of these practices. Argentinean extension educators could benefit from exchange programs with countries such as the United States and Australia that face similar challenges with herbicide resistance.

Sklenicka et al. (2015) identified three motivational categories underlying adoption of management practices by farmers: decisions based on personal values, decisions based on economic incentives, and decisions driven by legal or regulatory restrictions. Arguably, the second two categories can be most effectively deployed in the Argentine Pampas. It will be difficult to implement changes in leasing and farming practices without government involvement, but the private sector has a vital role to play. Agrochemical companies, for example, might benefit from promoting resistance management to their customers as a way to maintain the efficacy and hence the sales of their products. The rapidly developing problem of herbicide-resistant weeds in Argentina is driven by complex interwoven economic, social, and political factors that shape current agricultural practices in the Argentine Pampas, and cannot be solved by relying only on market forces or grower education. A solution will also depend on economic and legal reforms that require government action. Argentina-for better or worse- has a history of government intervention (or attempted intervention) in national agricultural production; for example, the imposition of crop export taxes and quotas, or the 
soil and weed management requirements written into the 1948 Land Lease Law. Argentina also has a history of agricultural producers ignoring or finding ways to circumvent laws perceived as unjust or burdensome. Any new legislation must therefore be effectively enforced, but new government regulation must also be understood and agreed to by those affected to be potentially beneficial instead of imposing unreasonable bureaucratic demands.

Neither landowners nor tenants will be willing to reduce their incomes by rotating from soybean to less profitable crops such as wheat or corn, unless the recently proposed changes in crop export taxes are implemented by the Argentine government. Landowners will also need to be convinced that the long-term benefits of managing herbicide resistance are worth the short-term costs. For example, offering longer leases with reduced initial rental rates on land infested with herbicide-resistant weeds might encourage tenants to invest in alternate management strategies, such as expanded crop rotations that would allow the use of more diverse MOAs. Such an approach would require changes in current land leasing practice, backed by legal reforms. This effort will not be easy, simple, or cheap: it will demand a long-term commitment to change agricultural practices as they currently exist in Argentina. However, without this commitment to change the problem of herbicide-resistant weeds will continue to increase, undermining the productivity of Argentine agriculture.

\section{Acknowledgments}

Claudio Rubione would like to thank Daniel Balmaceda, Eduardo Firpo, Paula Lleras, Dale Shaner, and Antonio Wojzsco for discussion, manuscript review, data sources, and suggestions; Ana Balbin for help with English translation; and Joaquin Disavia for taking his place in the field and allowing him time to write. The authors also thank two anonymous reviewers for suggestions that greatly improved the manuscript.

\section{Literature Cited}

AAPRESID (2012) Evolución de la superficie en siembra directa en Argentina. Asociación Argentina de Productores en Siembra Directa. http://www.aapresid.org.ar/wpcontent/uploads/2013/ 02/aapresid.evolucion_superficie_sd_argentina.1977_a_2011. pdf. Accessed January 25, 2016

AAPRESID REM (2015) Asociación Argentina de Productores en Siembra Directa: Red de Conocimiento de Malezas
Resistentes. http//www.aapresid.org.ar/rem. Accessed July 29, 2015

AFIP (2007) Resolución General 2300. http://www.infoleg.gob. ar/infolegInternet/anexos/130000-134999/131965/norma. htm. Accessed March 26, 2016

Amaral S (1998) The Rise of Capitalism on the Pampas: The Estancias of Buenos Aires 1785-1870. Cambridge, UK: Cambridge University Press. $382 \mathrm{p}$

Anonymous (2014) Argentina's Wheat Exports: Against the Grain. http://www.economist.com/blogs/americasview/2014/ 01/argentinas-wheat-exports. Accessed January 26, 2016

Barsky O, Becker V, Bearzotti S, Bocco A, Keller D, Solá F (1991) El Desarrollo Agropecuario Pampeano. San Isidro, Costa Rica: Instituto Interamericano de Cooperación para la Agricultura. Pp 309-399

Bert FE, Podesta GP, Rovere SL, Menendez AN, North M, Tatara E, Laciana CE, Weber E, Toranzo FR (2011) An agent based model to simulate structural and land use changes in agricultural systems of the Argentine pampas. Ecol Model 222:3486-3499

Binimelis R, Pengue W, Monterroso I (2009) "Transgenic treadmill": responses to the emergence and spread of glyphosate-resistant johnsongrass in Argentina. Geoforum 40:623-633

Bronstein H (2015) Argentina in for a Radical Post-Election Grains Output Increase. http://www.reuters.com/article/usargentina-election-grainsidUSKBN0TC0BY20151123. Accessed January 25, 2016

Cabrini SM, Calcaterra CP (2016) Modeling economicenvironmental decision making for agricultural land use in Argentinean Pampas. Agric Sys 143:183-194

Choumert J, Phelinas P (2015) Farmland Rental Values in GM Soybean Areas of Argentina: Do Contractual Arrangements Matter? Etudes et Documents No. 32. CERDI. http://cerdi. org/production/show/id/1764/type production id/1. Accessed January 16, 2016

Compañía Argentina de Tierras (2016) Evolución del Precio de Arrendamientos para Soja en Zona Núcleo Maicera. http:// www.cadetierras.com.ar. Accessed January 16, 2016

Delvenne P, Vasen F, Vara AM (2013) The "soy-ization" of Argentina: the dynamics of the globalized privatization regime in a peripheral context. Technol Soc 35:153-162

Fernández DA (2010) Cómo calcular la unidad económica en el agro? La incidencia de la renta de la tierra. Pages 2-5 in Actas de las XVI Jornadas de Epistemología de las Ciencias Económicas. Buenos Aires, Argentina: Universidad de Buenos Aires

Fraser EDG (2004) Land tenure and agricultural management: soil conservation on rented and owned fields in southwestern British Columbia. Agric Hum Values 21:73-79

Heap I (2016) The International Survey of Herbicide Resistant Weeds. http://www.weedscience.org. Accessed January 20, 2016

Leguizamón A (2014) Modifying Argentina: GM soy and socioenvironmental change. Geoforum 53:149-160

Lemke AM, Lindenbaum TT, Perry WL, Herbert ME, Tear TH, Herkert JR (2010) Effects of outreach on the awareness and adoption of conservation practices by farmers in two agricultural watersheds of the Mackinaw River, Illinois. J Soil Water Conserv 65:304-315

Llewellyn RS, Allen DM (2006) Expected mobility of herbicide resistance via weed seeds and pollen in a Western Australian cropping region. Crop Prot 25:520-526 
Manciana E, Trucco M, Piñeiro M (2009) Large-Scale Acquisition of Land Rights for Agricultural or Natural Resource-Based Use: Argentina. http://dx.doi.org/10.2139/ ssrn.1915343. Accessed October 17, 2015

Mander B (2015) Mauricio Macri Scraps Tax on Argentine Farm Exports. http://www.ft.com/cms/s/0/3f7cf388-a27511e5-8d70-42b68cfae6e4.html. Accessed January 25, 2016

Norsworthy JK, Ward SM, Shaw DR, Llewellyn RS, Nichols RL, Webster TM, Bradley KW, Frisvold G, Powles SB, Burgos NR, Witt WW, Barrett M (2012) Reducing the risks of herbicide resistance: best management practices and recommendations. Weed Sci 60(sp 1):31-62

Penna JA, Lema D (2003) Adoption of herbicide tolerant soybeans in Argentina: an economic analysis. Pages 203-220 in Kalaitzandonakes N, ed. Economic and Environmental Impacts of Agrotechnology. New York: Kluwer-Plenum

Propoky LS, Floress K, Klotthor-Weinkauf D, Baumgart-Getz A (2008) Determinants of agricultural best management practice adoption: evidence from the literature. J Soil Water Conserv 63:300-311

Qaim M, Traxler G (2005) Roundup Ready soybeans in Argentina: farm level and aggregate welfare effects. Agric Econ 32:73-86

Riar DS, Norsworthy JK, Steckel LE, Stephenson DO, IV, Eubank, TW, Bond J, Scott RC (2013) Adoption of best management practices for herbicide-resistant weeds in midsouthern United States cotton, rice, and soybean. Weed Technol 27:788-797

Rótolo GC, Montico S, Francis CA, Ulgiati S (2015) How land allocation and technology innovation affect the sustainability of agriculture in Argentina Pampas: an expanded life cycle analysis. Agric Sys 141:79-93

SAIJ (2016) Sistema Argentino de Información Jurídica. http:// www.infojus.gob.ar. Accessed March 26, 2016

Senesi S, Dulce E, Daziano M, Ordóñez I, Luis Mogni L (2016) La Soja en Argentina: Un Sistema de Agronegocios Clave y Competitivo. La Lucila, Argentina: Marcos Fabrizio Daziano. $244 \mathrm{p}$

Senesi S, Ordoñez I (2013) Impacto Económico Macro y Micro de Malezas Resistentes en el Agro Argentino. http://issuu.com/ luisgaletto/docs/libro_digital_adama_fauba_impacto_m. Accessed July 29, 2015

Senesi SI, Palau H, Chaddad FR, Daziano M (2013) The evolution of farming networks in a fragile institutional environment: the case of Argentina. J Chain Netw Sci $13: 71-82$

Shaner D (2000) The impact of glyphosate-tolerant crops on the use of other herbicides and on resistance management. Pest Manag Sci 56:320-326

SIIA (2016) Sistema Integrado de Información Agropecuaria. http://www.siia.gov.ar. Accessed March 29, 2016

Sili M, Soumoulou L (2011) La Problemática de la Tierra en Argentina. Rome, Italy: Fondo Internacional de Desarollo Agrícola. $176 \mathrm{p}$

Sklenicka P, Molnarova KJ, Salek M, Simova P, Vlasak J, Sekac P, Janovska V (2015) Owner or tenant: Who adopts better soil conservation practices? Land Use Policy 47:253-261

Soule MJ, Tegene A, Wiebe KJ (2000) Land tenure and the adoption of conservation practices. Am J Agric Econ 82:9931005

Tomei J, Upham P (2009) Argentinean soy-based biodiesel: an introduction to production and impacts. Energy Policy 37:3890-3898

Urcola HA, de Sartre XA, Veiga I, Elverdin J, Albaladejo C (2015) Land tenancy, soybean, actors and transformations in the Pampas: a district balance. J Rural Stud 39:32-40

Varble S, Secchi S, Druschke SG (2016) An examination of growing trends in land tenure and conservation practice adoption: results from a farmer survey in Iowa. Environ Manag 57:318-330

Viglizzo EF, Ricard MF, Jobbagy EC, Frank FC, Carreño LV (2011) Assessing the cross-scale impact of 50 years of agricultural transformation in Argentina. Field Crops Res 124:186-194

Vila-Aiub MM, Balbi MC, Gundel PE, Ghersa CM, Powles SB (2008a) Evolution of glyphosate-resistant johnsongrass (Sorghum halepense) in glyphosate-resistant soybean. Weed Sci 55:566-571

Vila-Aiub MM, Vidal RA, Balbi MC, Gundel PE, Trucco F, Ghersa CM (2008b) Glyphosate-resistant weeds of South American cropping systems: an overview. Pest Manag Sci 64:366-371

Received January 30, 2016, and approved April 11, 2016.

Associate Editor for this paper: William Vencill, University of Georgia. 